\title{
Inorganic particulates in pneumoconiotic lungs of hard metal grinders
}

\author{
J R RÜTTNER, M A SPYCHER, I STOLKIN \\ From the Institute of Pathology, University Hospital, Zürich, and Zürich Pneumoconiosis Research Group, \\ Zürich, Switzerland
}

\begin{abstract}
Data from the analysis of lung dust in 16 metal grinders who had been exposed to hard metals between five and 44 years is reported. The mean latent time between the first exposure and analysis in biopsy or necropsy specimens was 33.6 years. Mineralogical and elementary analysis by a variety of techniques showed small or trace amounts of hard metal in all lungs. Many specimens, however, did not contain all hard metal components, cobalt, for example, being detected in four cases only. All the lungs contained quartz and silicates and in most of the necropsy cases carborundum and corundum could also be shown. Histologically no specific pattern was found. The appearances included mixed dust nodular pneumoconiosis, diffuse interstitial lung fibrosis, and foreign body and sarcoid like granulomatous changes. In view of the mixed dust exposure of the hard metal grinders and the variable histological appearance we think that the term "mixed dust pneumoconiosis in hard metal grinders" is more appropriate than "hard metal lung" to describe this condition.
\end{abstract}

The mineralogical and chemical analysis of lung tissue has proved successful in detecting aetiological particulates in the pneumoconioses. This is particularly true for the uncommon pneumoconioses, to which group belong the rare cases of Cerpneumoconiosis ${ }^{12}$ and the so called hard metal disease that has attracted considerable attention since it was first described by Jobs and Ballhausen in Germany in $1940 .^{3}$

Hard metals are metallurgical materials characterised by their extreme physical hardness and resistance to corrosion and heat, and they have found wide application in industries such as toolmaking, instrument production, and the manufacture of drills. The process of manufacturing hard metals includes the sintering of powders of tungsten carbide (WC), titanium carbide ( $\mathrm{TiC})$, niobium carbide $(\mathrm{NbC})$, tantalum carbide $(\mathrm{TaC})$, molybdenum carbide (MoC), vanadium carbide (VC), and chromium carbide $(\mathrm{CrC})$, with cobalt $(\mathrm{Co})$ and nickel $(\mathrm{Ni})$ as binding materials. The composition varies according to the technical requirements. Tungsten carbide (WC) is the main component and is regularly present in high amounts, around $80-90 \%{ }^{4}$ More than $75 \%$ of hard metals contain between $6 \%$ and $9 \%$ cobalt. ${ }^{5}$ Dust is produced both in the manufacture of hard metals and

Accepted 20 October 1986 during the grinding and polishing of hard metal products. In Switzerland, with a highly developed toolmaking industry, instrument grinders are especially exposed. Grinders usually use corundum $\left(\mathrm{Al}_{2} \mathrm{O}_{3}\right)$, carborundum ( $\mathrm{SiC}$ ), and diamond buffing disks. Dust measurement studies in the patients' working environment report concentrations of particles below 5 microns of between $0.3 \mathrm{mg} / \mathrm{m}^{35}$ and $15 \mathrm{mg} / \mathrm{m}^{3}$ and more. ${ }^{6}$ The particle size in the working area varies between 1 and 20 microns. $^{7}$

Clinically, two types of hard metal induced lung lesions are described: (1) diffuse interstitial lung fibrosis with a restrictive impairment of lung function and (2) hard metal asthma with an obstructive disturbance. ${ }^{489}$ Pathologically, an interstitial lung fibrosis has been reported in most of the published cases. ${ }^{10-20}$

In the present paper we report the results of a mineralogical analysis of lung dust in 16 metal grinders and polishers exposed to hard metal dust.

\section{Occupational history and dust exposure}

Of the 16 patients, 15 had a clear history of exposure to hard metal dust. In one case (No 547), a 74 year old man, no occupational data were available but lung dust analysis was performed because of clinical idiopathic diffuse lung fibrosis and the presence of hard 
Table 1 Hard metal grinders: exposure time and age distribution

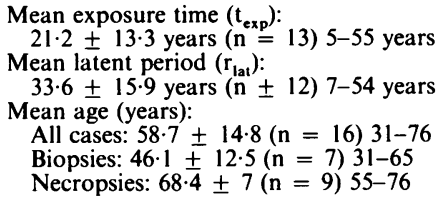

metals was shown. The 15 subjects had been metal grinders, polishers, and winders in plants where hard metal tools and instruments were produced. Two of the patients had worked as grinders in foundries (Nos 253,792 ), another (No 758) had worked in a quartz mill before working as a grinder. None had been engaged in the manufacture of hard metals. Unfortunately the data about dust concentration at their places of work are incomplete. In many cases the exposure was in the distant past and apparently low. Single measurements resulted in values around $1.3-2.8 \mathrm{mg} / \mathrm{m}^{3}$ but in one extreme case it was up to $15.6 \mathrm{mg} / \mathrm{m}^{3}$ (Swiss National Accident Insurance Fund (SNAIF), personal communication). The patients had frequently been exposed to mixed dust containing particles other than hard metals. These values, however, may not be representative. Reliable values for the concentration of cobalt in the working atmosphere are also not available. In one case, however, it was estimated to be $0 \cdot 1 \mathrm{mg} / \mathrm{m}^{3}$ (SNAIF).

Table 1 documents the average exposure time $\left(t_{\exp }\right)$ and the latent period $\left(t_{\text {lat }}\right)$ between the first contact with hard metal dust and the time of analysis-that is, the time of biopsy or necropsy. The shortest exposure time was five years and the longest 44 years. The mean latent time ( 12 cases) was 33.6 years.

The ages at diagnosis ranged between 31 and 62 in the biopsy cases and between 55 and 76 in the nec-? ropsy cases (table 1).

\section{Histological findings}

The histological findings are given in table 2. In three $\frac{\widehat{\Phi}}{\mathrm{D}}$ cases (Nos 253, 296, 758) there was a mixed dust pneumoconiosis of the type seen in foundry workerses with starlike pinhead sized nodules that showed $\vec{\circ}$ fibrosis accompanied by centrilobular emphysema. ${ }^{21} \vec{\overrightarrow{ }}$

In 10 cases there was a diffuse interstitial lung $\vec{\omega}$ fibrosis (DILF) with honeycombing. In two of these (Nos 511 and 880) the DILF was associated with $\frac{\mathbb{}}{3}$ granulomatous lesions having an appearance like sar-i coidosis. Three biopsy cases showed granulomatous lesions only. In two (Nos 451, 454) there was a foreigno body reaction with giant cells containing dust par-जे ticles. The third case showed sarcoid like granulomas.

\section{Analytical methods and results}

We used seven lung biopsy specimens and nine whole lungs from necropsies for lung dust analysis. For isolation of the minerals the lungs and the biopsy speci- $\vec{\bullet}$ mens were degraded either by plasma incineration 80 by formamide. The procedures used are described ${ }^{2} n$ full elsewhere. ${ }^{22} 23$

To identify mineralogical particulates in biopsy specimens we used transmission electron microscopyo and energy dispersive $x$ ray analysis (EDXA) on thing sections from histological preparations.

In necropsy cases representative probes of isolated $\overrightarrow{\overrightarrow{0}}$ lung dust were used for $x$ ray diffraction and infrared $\exists$

Table 2 Exposure time and pathological diagnoses

\begin{tabular}{|c|c|c|c|c|}
\hline Case no & Age (years) & $t_{\text {exp }}$ Years & $t_{\text {lot }}$ Years & Diagnosis \\
\hline $\begin{array}{l}\text { Biopsies } \\
451 \\
454 \\
584 \\
627 \\
669 \\
694 \\
792\end{array}$ & $\begin{array}{l}40 \\
31 \\
43 \\
39 \\
43 \\
62 \\
62\end{array}$ & $\begin{array}{r}18 \\
15 \\
16 \\
13 \\
7 \\
- \\
-\end{array}$ & $\begin{array}{r}21 \\
22 \\
16 \\
7 \\
-\end{array}$ & $\begin{array}{l}\text { GRAN (F) } \\
\text { GRAN (F) } \\
\text { GRAN (S) } \\
\text { DILF } \\
\text { DILF } \\
\text { DILF } \\
\text { DILF }\end{array}$ \\
\hline $\begin{array}{l}\text { Necropsies } \\
253 \\
296 \\
511 \\
547 \\
578 \\
672 \\
724 \\
758 \\
880\end{array}$ & $\begin{array}{l}72 \\
65 \\
55 \\
74 \\
71 \\
66 \\
75 \\
76 \\
62\end{array}$ & $\begin{array}{r}5 \\
22 \\
36 \\
32 \\
43 \\
44 \\
9 \\
16\end{array}$ & $\begin{array}{l}51 \\
23 \\
41 \\
38 \\
47 \\
54 \\
53 \\
30\end{array}$ & $\begin{array}{l}\text { MIPN }+++ \\
\text { MIPN }+ \\
\text { DILF }++ \text { GRAN (S) } \\
\text { DILF }+++ \\
\text { DILF }+++ \\
\text { DILF }+++ \\
\text { DILF }+++ \\
\text { MIPN }++ \\
\text { DILF }+ \text { GRAN (S) }\end{array}$ \\
\hline
\end{tabular}

MIPN = Mixed dust pneumoconiosis; DILF = diffuse interstitial lung fibrosis; GRAN = granulomatous changes; severity: $+=$ mild, $++\square$ $=$ moderate,$+++=$ severe; $t_{\text {exp }}=$ time of dust exposure; $t_{\text {lat }}=$ time between first exposure to dust and biopsy or necropsy; $(F)=$ foreig $\bar{Z}$ body reaction; $(\mathbf{S})=$ sarcoid like. 
Table 3 Elemental analysis (AAS, EDXA)

\begin{tabular}{|c|c|c|c|}
\hline $\begin{array}{l}\text { Case } \\
\text { No }\end{array}$ & $\begin{array}{l}\text { Hard metal } \\
\text { components }\end{array}$ & $\begin{array}{l}\text { Binding } \\
\text { metals }\end{array}$ & Other elements \\
\hline & & \multicolumn{2}{|c|}{ Biopsy specimens: } \\
\hline 451 & $\mathbf{W}$ & $\mathrm{Fe}, \mathrm{Ni}$ & $\mathrm{Cu}, \mathrm{Al}, \mathrm{P}, \mathrm{Si}, \mathrm{S}, \mathrm{Mg}, \mathrm{Ca}, \mathrm{K}$ \\
\hline 454 & $\mathrm{Ti}, \mathrm{W}$ & $\mathrm{Fe}$ & $\mathrm{Al}, \mathrm{Mn}, \mathrm{Cu}, \mathrm{Zn}, \mathrm{Si}, \mathrm{P}$ \\
\hline 584 & $\mathrm{Ti}, \mathrm{Cr}$ & $\mathrm{Co}, \mathrm{Fe}, \mathrm{Ni}$ & $\mathrm{Al}, \mathrm{Ce}, \mathrm{P}, \mathrm{Si}$ \\
\hline 627 & $\mathrm{Nb}, \mathrm{Ti}, \mathrm{W}, \mathrm{Cr}$ & $\mathrm{Fe}, \mathrm{Ni}$ & Mo, Al, Si, Ca, K, P, Sn, Cl \\
\hline 669 & $\mathrm{Ti}, \mathrm{W}, \mathrm{Cr}$ & $\mathrm{Fe}, \mathrm{Ni}$ & $\mathrm{Al}, \mathrm{Ca}, \mathrm{Si}$ \\
\hline $\begin{array}{l}694 \\
792\end{array}$ & $\mathrm{Ti}, \mathbf{W}, \mathrm{Zr}, \mathrm{Cr}$ & $\mathrm{Fe}, \mathrm{Ni}$ & $\mathrm{Si}, \mathrm{Al}, \mathrm{Ba}, \mathrm{Ca}$ \\
\hline & $\mathrm{Ti}, \mathrm{W}, \mathrm{Cr}$ & $\mathrm{Fe}, \mathrm{Ni}$ & $\mathrm{Al}, \mathrm{P}, \mathrm{Si}, \mathrm{Zn}, \mathrm{Sn}, \mathrm{S}$ \\
\hline
\end{tabular}

spectroscopy and also for electron microscopy and EDXA. In some instances atomic absorption spectroscopy (AAS) was applied. The results are summarised in tables 3 (biopsy specimens, elemental analysis) and 4 (necropsies, elemental and mineralogical analysis).

It has to be emphasised that it is not always possible to correlate the results of the EDXA analysis with the results of the mineralogical analysis. The EDXA method allows for the detection of elements with an atomic number greater than $9(\mathrm{~F})$ only. The sensitivity of EDXA is much higher than the $x$ ray diffraction and infrared-spectroscopy methods. For example, small quantities of $\mathrm{Cr}$ and $\mathrm{Co}$ were detected with EDXA in case No 547 whereas no corresponding compounds of these elements were observed with $x$ ray diffraction and infrared-spectroscopy. The EDXA analysis of biopsy specimens allows only the detection of elements but no compounds. In combination with other methods and the occupational history it is a valuable indicator for a given dust exposure.
Discussion

In all the lungs analysed hard metal components were found. Not all the isolated dust samples, however, contained all the most frequently used hard metal components, thus $\mathrm{W}, \mathrm{Mo}, \mathrm{Ti}, \mathrm{Cr}$, and Co were not detected in each and every lung. Apart from the hard metals, considerable amounts of quartz and silicates such as mica and feldspar, and other minerals were also present in all the lungs. In the lungs showing mixed dust pneumoconiosis the mineral content of the lung was high (with the exception of case 296) compared with the cases with diffuse interstitial lesions. Carborundum and corundum, the most frequently used grinding materials, were found in seven of the nine necropsy lungs of metal grinders that have been analysed in total. In the biopsy tissue, however, as mentioned before, carborundum and corundum could not be shown by EDXA analysis.

Histologically three types of lung lesions were found:

(1) diffuse interstitial lung fibrosis (DILF),

(2) sarcoid like granulomatous lesions and foreign body reactions (GRAN), and

(3) typical mixed dust pneumoconiosis with starlike elementary nodules (mixed dust silicosis) (MIPN).

The histological pattern was not always uniform and different lesions often appeared in the same lung. No specific changes induced by hard metal were detected. This is perhaps what would be expected as it is not the hard metals alone but dust mixtures containing other fibrogenic mineral particles such as

Table 4 Elemental analysis (AAS, EDXA)

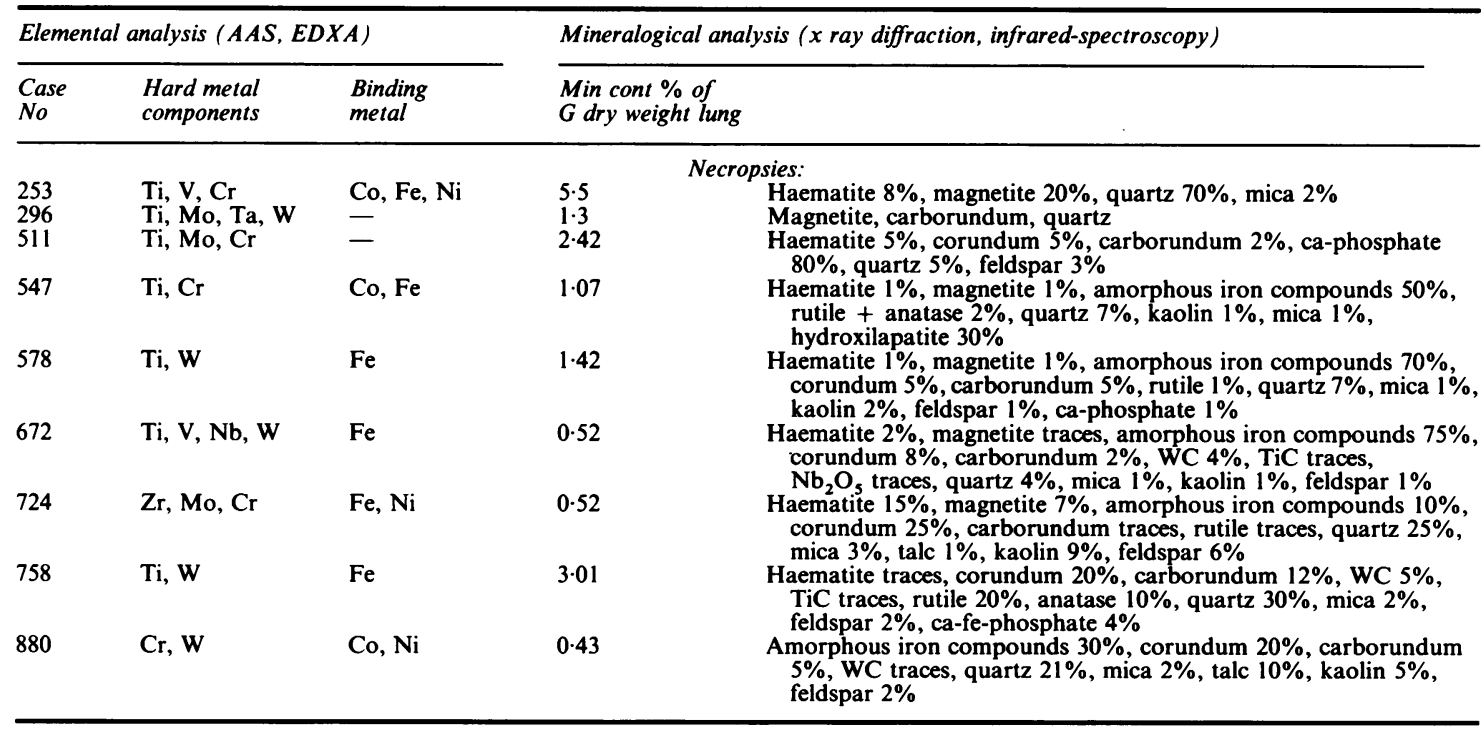


quartz and silicates which are inhaled. These other minerals probably play a contributory part in inducing the lung changes. From our experience we know that plate minerals and fibrous minerals (mica, for example) produce a diffuse interstitial fibrosis. ${ }^{24}$ The aetiological and pathogenic role of the metal binding cobalt is unclear in this process. From clinical evidence it seems that cobalt may be responsible for the asthmatic form of hard metal disease. Cobalt increases the risk of asthma five times when an exposure at a concentration of $0.1 \mathrm{mg} / \mathrm{m}^{3}$ occurs. $^{25}$ Other authors suspect that cobalt is an important causal agent in hard metal disease. ${ }^{171826-28}$ The search for cobalt by chemical and mineralogical analysis of lung tissue was not, however, rewarding and it was found in four cases only. This may be a consequence of the high solubility of this metal in water by which it evades detection.

Nevertheless, based on clinical observation cobalt may have a toxic allergic influence. ${ }^{4172529}$ The origin of the sarcoid like lung lesions may be a cobalt mediated immunological process. Analysis of giant cells with the electron microscope and EDXA in our material, however, showed no cobalt. Instead the particulates sometimes seen in the foreign body giant cells resembled quartz crystals and micacrystals. Measurements of particles containing tungsten in the electron microscope and in some of the deposits in the fibrosed interstitial lung tissue showed that most are less than 1 micron in diameter. These small particles, together with the fibrogenic plate minerals (silicates), are believed to be an essential factor in the production of diffuse interstitial lung fibrosis.

Taking the results of the analysis and the histopathological features together there appears to be no specific lung lesion in workmen exposed to hard metal. The appearances are rather those of a nonspecific mixed dust pneumoconiosis. For this reason we prefer the term "pneumoconiosis in hard metal grinders" to "hard metal lung" which we do not believe is a distinct pathological entity.

\section{References}

1 Vogt P, Spycher MA, Rüttner JR. Pneumokoniose durch "Seltene Erden" (Cer-Pneumokoniose). Schweiz Med Wochenschr 1986;116:1303-8.

2 Sabbioni E, Pietra R, Gaglione P, et al. Long-term occupational risk of rare-earth pneumoconiosis (a case report as investigated by neutron activation analysis). Science of the Total Environment 1982;26:29-32.

3 Jobs H, Ballhausen C. Metallkeramik als Staubquelle vom ärztlichen und technischen Standpunkt. Vertrauensarzt 1940;8:142-8.

4 Kusaka Y, Yokoyama K, Sera Y, et al. Respiratory diseases in hard metal workers: an occupational hygiene study in a factory. Br J Ind Med 1986;43:474-85.

5 Bech AO, Kipling MD, Heather JC. Hard metal disease. Br J Ind Med 1962;19:239-52.

6 Reber E, Burckhardt P. Ueber Hartmetallstaublungen in der Sch- wèiz. Respiration 1970;27:120-53.

7 Einbrodt HJ, Fitzek J. Untersuchungen des Lungenstaubes bei $\underset{\mathbb{D}}{\lessgtr}$ Hartmetallfibrose. Internationale Archiv für Gewerbepathologie 을 und Gewerbehygiene 1962;19:651-9.

8 Scherrer M, Maillard JM. Hartmetall-Pneumopathien. Schweiz Med Wochenschr 1982;112:198-207.

9 Hartmann A, Wuthrich B, Bolognini G. Berufsbedingte Lungenkrankheiten bei der Hartmetallproduktion und bearbeitung. Ein allergisches Geschehen? Schweiz Med Wochenschr 1982;112:1137-41.

10 Lundgren KD, Oehman H. Pneumokoniose in der Hartmetallindustrie. Technische und medizinische Untersuchungen. Virchows Arch Pathol Anat 1954;325:259-84.

11 Husten K. Hartmetallfibrose der Lunge. Internationale Archiv für $\vec{\ominus}$ Gewerbepathologie und Gewerbehygiene 1959;16:721-32.

12 Moschinski GA, Jurisch A, Reinl W. Die Lungenveränderungen $\vec{\omega}$ bei Sinterhartmetall-Arbeitern. Internationale Archiv für $\frac{\Omega}{O}$ Gewerbepathologie und Gewerbehygiene 1959;16:697-720.

13 Kühne W. Die pathologische Anatomie der Lungenfibrose durch Hartmetall. Internationale Archiv für Gewerbepathologie und is Gewerbehygiene 1962;19:633-50.

14 Einbrodt HJ, Kühne W. Lungenstaub und morphologisches Bild $\overrightarrow{0}$ einer Hartmetallfibrose. In: Reploh H, Klosterkötter W, eds. 'ं Fortschritte der Staublungenforschung. Dinslaken: Nieder- G rheinische Druckerei GmbH, 1963:217-22.

15 Coates EO, Watson JHL. Pathology of the lung in tungsten car- 윽 bide workers using light and electron microscopy. J Occup Med 1973;15:280-6.

16 Baudouin J, Jobard $P$, Moline J, Lavandier $M$, Roullier A, Homasson JP. Fibrose pulmonaire interstitielle diffuse, $\frac{O}{O}$ responsabilité des métaux durs. Nouvelle Presse Medicale 므 1975;4:1353-5.

17 Kitamura H, Tozawa T, Kimura Y. Cemented tungsten carbide $\overrightarrow{0}$ pneumoconiosis. Acta Pathologica Japanica 1978;28:921-35 \

18 Hartung $M$, Valentin $H$. Lungenfibrosen durch Ha metallstäube. Zentralblatt Bakteriologie, Parasitenkunde Infektionskrankheiten und Hygiene Abteilung 1 Originale Reif B 1983;177:237-50.

19 Morgenroth K. Hartmetall-Lunge. Atemwegs- und Lungenkrankheiten 1985;11:260-4.

20 Rüttner JR, Furrer CF. Die Pathologie der sogenannten $\stackrel{\mathbb{D}}{\mathrm{Q}}$ "Hartmetallstaub-Lunge" und vergleichende Lungen- $\vec{F}$ staubanalysen. Zeitschrift für Unfallmedizin und Berufs- 윽 krankheiten 1982;75:191-7.

21 Rüttner JR. Foundry workers' pneumoconiosis in Switzerland (anthracosilicosis). Archives of Industrial Hygiene and Occupational Medicine 1954;9:297-305.

22 Rüttner JR, Spycher MA, Sticher H. The detection of etiologic $\mathbb{D}$ agents in interstitial pulmonary fibrosis. Hum Pathol 3 1973;4:497-512.

23 Abraham JL. Analysis of particulates in tissues. In: Hill RB, Terzian JA, eds. Environmental pathology: an evolving field. New York: AR Liss, Inc, 1982:229-41.

24 Rüttner JR, Spycher MA, Sticher H. Diffuse "asbestosis-like" interstitial fibrosis of the lung. Pathologia et Microbiologia $\mathrm{O}$ 1972;38:250-7.

25 Roto P. Asthma, symptoms of chronic bronchitis and ventilatory capacity among cobalt and zinc production workers. Scand $J$ ‥ Work Environ Health 1980;6,suppl 1:1-49.

26 Sprince NL, Chamberlin RI, Hales CH, Weber AL, Kazemi H. O Respiratory disease in tungsten carbide production workers. $\mathrm{N}$ Chest 1984;86:549-57.

27 Demedts M, Gheysens B, Nagels J, et al. Cobalt lung in diamond $\omega$ polishers. Am Rev Respir Dis 1984;130:130-5.

28 Hartung M, Schaller KH, Brand E. On the question of the pathogenic importance of cobalt for hard metal fibrosis of the lung. Int Arch Occup Environ Health 1982;50:53-7.

29 Sjogren I, Hillerdal G, Andersson A, Zetterstrom O. Hard metal $\stackrel{\mathscr{C}}{+}$ lung disease: importance of cobalt in coolants. Thorax $\square$ 1980;35:653-9. 